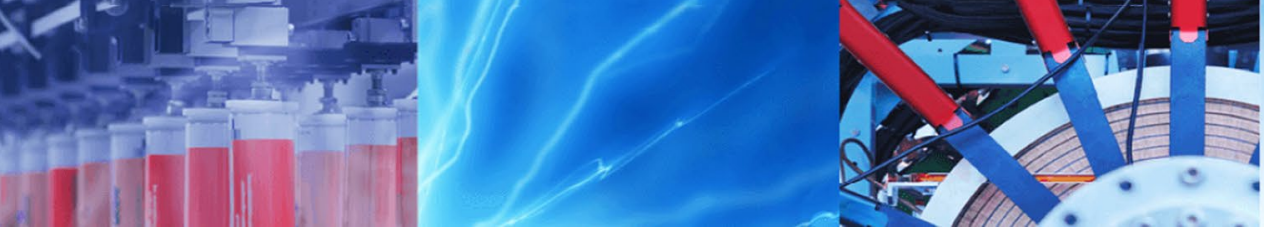

Research Article

\title{
Increase in the bioavailability of trace metals after sediment resuspension
}

\author{
Alexandre Rafael de Freitas ${ }^{1}$ (D) Ana Paula de Castro Rodrigues ${ }^{2} \cdot$ Christiane do Nascimento Monte $^{3}$. \\ Aline Soares Freire ${ }^{4} \cdot$ Ricardo Erthal Santelli ${ }^{4} \cdot$ Wilson Machado ${ }^{5} \cdot$ Elisamara Sabadini-Santos $^{5}$
}

(c) Springer Nature Switzerland AG 2019

\begin{abstract}
This study evaluated the potential mobility of metallic contaminants $(\mathrm{Cd}, \mathrm{Cr}, \mathrm{Cu}, \mathrm{Ni}, \mathrm{Pb}$ and $\mathrm{Zn})$ present in sediments at the mouth of São Francisco Channel (Sepetiba Bay, RJ), using resuspension tests. Fourteen surface sediment and superficial water samples were collected along a salinity gradient from the river mouth into the bay. The resuspension tests consisted in the mechanical agitation of humid sediment aliquots in local unfiltered water, in a ratio of $7.5 \mathrm{~g}: 100 \mathrm{~mL}$, during $1 \mathrm{~h}$ and $24 \mathrm{~h}$. The determination of the metals in the bioavailable fraction was performed in ICP-OES, after extraction in $1 \mathrm{~mol} \mathrm{~L}^{-1}$ $\mathrm{HCl}$. Significant differences were observed between the central and external sectors for $\mathrm{Cd}(p=0.009), \mathrm{Cr}(p=0.017), \mathrm{Ni}$ $(p=0.047)$ and $\mathrm{Zn}(p=0.007)$ concentrations (Kruskal-Wallis). The water's temperature $(p<0.001), \mathrm{pH}(p<0.05)$ and dissolved oxygen $(p<0.001)$ decreased in both time intervals in comparison to the initial measures before resuspension. The concentrations of $\mathrm{Zn}$ in the sediment increased from 222 to $316.2 \mathrm{mg} \mathrm{kg}^{-1}$ after $24 \mathrm{~h}$ agitation (Kruskal-Wallis; $p<0.05$ ) at the external sector, possibly because this region has stronger oxidizing conditions. In general, a significant increase in the metals' concentrations was observed after resuspension, especially for the samples from the central sector that showed more than $90 \%$ of increase in metals concentrations after $24 \mathrm{~h}$ of agitation. These increases could lead to higher ecological risks to the local biota, especially during dredging activities.
\end{abstract}

Keywords Pollution · Resuspension · Metals · Sepetiba Bay · Dredging

\section{Introduction}

Metals occur naturally in the environment, with their origin on the weathering process of rocks, gasification and volcanic activities. However, anthropogenic sources such as emissions from industrial effluents, domestic sewage, solid wastes and mining tailings have led to an increase in the concentration of these elements in aquatic ecosystems [51]. Contamination by metals has become an environmental problem of particular interest given the potential for bioaccumulation and toxicity. All metals, both essential and nonessential, may be toxic to animals and humans if the doses to which they are exposed are sufficiently high [39].

Once in the aquatic ecosystem, metals may be bounded to the suspended matter or sediment, as well as to be in the dissolved phase in surface or interstitial water. The removal of metals from the water column and their deposition in sediments depends on the physicochemical conditions $(\mathrm{pH}$, oxi-reduction potential, salinity, among

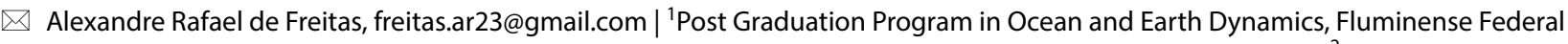
University - UFF, Campus Praia Vermelha, Av. Gen. Milton Tavares de Souza s/n', Niterói, RJ CEP: 24210-346, Brazil. ${ }^{2}$ Marine Biology Department, Centre of Health Sciences, Federal University of Rio de Janeiro - UFRJ, Block A, $1^{\circ}$ floor, Rio de Janeiro, RJ CEP: 21941-570, Brazil. ${ }^{3}$ Geology Department, Federal University of West Pará - UFOPA, Campus Tapajós, R. Vera Paz, s/n, Santarém, PA CEP: 68040-255, Brazil. ${ }^{4}$ Chemistry Institute, Federal University of Rio de Janeiro - UFRJ, Av. Pedro Calmon, 550, Rio de Janeiro, RJ CEP: 21941-901, Brazil. ${ }^{5}$ Geochemistry Department, Fluminense Federal University - UFF, Campus Valonguinho, Outeiro São João Batista, s/n, Niterói, RJ CEP: 24020-005, Brazil.
} 
others), as well as on the interaction between particles and dissolved organic and inorganic substances [4]. These factors in conjunction with several processes like bioturbation, adsorption, desorption, flocculation, diffusion and mobilization will define the dynamics of these metals in the environment, especially in relation to metal exchange between solid and dissolved phases [8]. These processes are observed in estuarine environments, especially due to the accentuated changes in the physicochemical characteristics of water, such as the increase in salinity. Seawater is rich in $\mathrm{Cl}^{-}$, a high electronegativity anion, capable of forming metal complexes. According to Eckert and Sholkovitz [15] and Dropo and Ongley [14], salinities from 1 to 5 are already capable to start flocculation processes, which allows the removal of metals from the dissolved phase by complexation in the solid phase.

In addition to the dose, the toxicity of a chemical element depends on the chemical form in which it is found in the environment $[31,32]$. Metals in the sediment can be in different chemical forms, called geochemical phases (exchangeable, oxidable, carbonate, reducible and residual), due to the environmental conditions of the sediment itself and also of the water column (such as grain size, $\mathrm{pH}$, salinity, organic matter content and oxidation conditions). Besides the release in the dissolved form, a change in this partitioning can alter the bioavailability of metals [31]. It is considered as a bioavailable geochemical phase, a substance that is found in forms that are weakly bounded to the sediment, capable of being absorbed by aquatic organisms [31, 36, 42].

Events such as storms, navigation or dredging may lead to resuspension of sediments into the water column, exposing them to different oxy-reduction conditions, which may result in the release of metals in the dissolved form [10]. When metals are released into the solution, the bioavailability of these metals increases, and the risk to aquatic life is expected to be intensified $[31,36,46,48$, 49]. Up to now, the processes involved in the control of the metals and persistent organic pollutants release during sediment resuspension events are not completely understood [9]. Maddock et al. [32] suggest that the combination of the characterization of the contributions and retention mechanisms of trace metals with the evaluation of the remobilization potential of these metals may allow a better understanding of (1) the processes that determine the partitioning of metals between solid phases and (2) the risk of remobilization due to disturbances that imply loss of stability of the chemical forms in which the metals are associated with the sediments and (3) how to predict the changes in superficial water quality due to the behavior of the metals.

There is a relatively small number of studies that conducted resuspension tests in order to understand the consequences of the resuspension of contaminants to the local biota. Cotou et al. [10], in a study in the northeast and northwest of the Mediterranean Sea, observed that sediment resuspension events are capable of influencing the chemical forms of micropollutants, thus increasing their bioavailability and toxicity (evaluated using the Microtox test with marine bacteria). Kim et al. [26], in Maryland (USA), using sediment, zooplankton and mollusk samples, have demonstrated that resuspension may play an important role in the transference of methylmercury from sediments to organisms. Cantwell et al. [9] used resuspension assays to understand the resuspension behavior of pollutants using sediments with previously known physical and chemical properties from Narragansett Town Beach (Rhode Island, USA) and observed a low release of metals in the dissolved phase in a short time scale. Kalnejais et al. [25] studied the release of nutrients and metals in resuspension events using an erosion chamber in Boston Harbor (Massachusetts, USA) and observed that sediment resuspension increased the release of nutrients and metals to the dissolved phase. Similarly, Fathollahzadeh et al. [16], studying the potential mobility of metals through resuspension tests of contaminated sediments under pseudodredging conditions in the port of Oskarshamn, Sweden, observed a potential release of $\mathrm{Cu}, \mathrm{Pb}, \mathrm{Zn}, \mathrm{Mn}$ and $\mathrm{Ni}$ to the environment.

In Brazil, Machado et al. [31] studying the potential mobility of $\mathrm{Cu}$ in surface sediments of Guanabara Bay, Rio de Janeiro State, Monte et al. [36] studying the bioavailability of $\mathrm{Zn}$ and $\mathrm{Cd}$ in contaminated sediments and Monte et al. [37] studying on the bioavailability of potentially toxic trace metals $(\mathrm{Cu}, \mathrm{Ni}$ and $\mathrm{Pb})$, both from the Engenho Creek, Sepetiba Bay, RJ, through resuspension tests, verified an increase in the concentrations of these metals in the bioavailable fraction in the sediments after the test. Rodrigues et al. [46, 48, 49], in a study with sediment profiles from Sepetiba Bay, RJ, verified that independently of the depth, there was a significant change in the physical-chemical conditions of the water and in the total organic carbon contents of the sediments after resuspension, which influenced the increase in the bioavailability of the $\mathrm{Cd}$. Therefore, the present study aimed to evaluate the mobility of metallic contaminants $(\mathrm{Cd}, \mathrm{Cr}, \mathrm{Cu}, \mathrm{Ni}, \mathrm{Pb}$ and $\mathrm{Zn}$ ) in sediments of the São Francisco Channel (Sepetiba Bay, RJ), by resuspension tests in an estuarine gradient and its relation with the physical-chemical characteristics, dissolved nutrients present in water and with the sediment characteristics (grain size, organic carbon content, Fe and $\mathrm{Mn}$ concentrations). As hypothesis, it is believed that an increase in the geochemical mobility of the metals in the sediment after resuspension occurs, as well as their relationship with the physical-chemical and nutrient concentrations on these compartments. 


\section{Methods}

\subsection{Study area}

The Sepetiba Bay is a semi-enclosed water body, located about $60 \mathrm{~km}$ south of Rio de Janeiro city, Brazil. It presents a typical hot-humid tropical climate, with an average annual rainfall of $1400 \mathrm{~mm}$, and a mean evaporation of $960 \mathrm{~mm}$ [21]. With a surface area of $520 \mathrm{~km}^{2}$, its dimensions are approximately $12.5 \mathrm{~km}$ (north-south) and $25 \mathrm{~km}$ (east-west), a volume of $3.5 \times 10^{9} \mathrm{~m}^{3}$. Approximately $50 \%$ of its area has less than $6 \mathrm{~m}$ of depth, varying from 2 to $12 \mathrm{~m}$, except in the three channels in the western sector, used for the port activities, being 24-31 m deep. According to Rocha et al. [45], its communication with the Atlantic Ocean occurs through two passages, one between the islands (Itacuruçá, Jaguanum and Pompeba) and the tip of Restinga da Marambaia, and another, the channel that flows into Barra de Guaratiba. Its tide is semi-diurnal, with diurnal inequality, and $99 \%$ of the bay's waves are less than $0.75 \mathrm{~m}$ [34].

Its drainage basin extends for $2710 \mathrm{~km}^{2}$ and covers 15 municipalities. It has a total population of about $7,851,139$ according to the 2010 census of the Brazilian Institute of Geography and Statistics (IBGE [24]). In the 1960s, the federal government implemented an industrial development program in the Sepetiba Bay drainage basin that led to the installation of more than 400 industries [27]. Among them, Mercantil Ingá Company (which went into bankruptcy in 1998) used to produce $\mathrm{Zn}$ and $\mathrm{Cd}$ of high purity from the calamine and willemite ore. Due to the low efficiency of the process, much of the metal originally contained in the ore remained in solid waste, which was stored in open-air yards and leached directly to the Engenho Creek region in Sepetiba Bay $[46,48,49]$. Even after 20 years, metals' concentrations in surface sediments are three to four orders of magnitude higher than the safety limits adopted by Brazilian legislation [7]. These thresholds are based on the Canadian Sediment Quality Guideline (SQG) that defined the limits of effects range low (ERL) and effects range median (ERM), which are representative of the probability of toxicity to biota. The Port of Itaguaí is one of the responsibles for the actual pollution scenario of Sepetiba Bay, because in addition to the great traffic of ships and constant dredging for the maintenance of its navigation channels, its location encouraged the installation of several industries.

From the 1950s and 1960s, after the transposition of water of the Paraíba do Sul River, the main freshwater inflow into the Sepetiba Bay started to be the São Francisco Channel, with a volume of $6538 \times 10^{6} \mathrm{~m}^{3}$ year $^{-1}$ and flow of $207.3 \mathrm{~m}^{3} \mathrm{~s}^{-1}$ [50]. This has led to the increase in solid inputs to the bay [35]. The San Francisco Channel is the final course of Guandu River and extends for $15 \mathrm{~km}$ until it drains into Sepetiba Bay. Its mouth is a delta in formation, with the presence of mangroves. The influence of the salt intrusion on the San Francisco Channel can extend up to $7 \mathrm{~km}$ from its mouth, depending on the river flow and the tide [22].

\subsection{Sampling procedures}

The campaign was conducted on May 3, 2012, after a week of intense rainfall, with an average rainfall of $8.6 \mathrm{~mm}$ (maximum of $42 \mathrm{~mm}$ ). The sample stations were located at the mouth of the São Francisco Channel and the sampling was carried out during the ebb tide. The surface sediment was sampled in fourteen stations, subdivided into three sectors: two stations in the internal sector, six in the central sector and six in the external sector (Fig. 1). As at the mouth of the channel, there is an island (Urubu Island), the river has its route divided, having a silted area due to the influence of the island in the hydrodynamics of that region. Therefore, for this work, it was chosen to sample in a transect from the innermost area (before the Urubu Island) toward the bay, on the left margin of the channel. The proposal is to verify along the transect possible differences in the geochemical mobility of metals according to the physical and chemical changes in sediments and water along a small-scale saline gradient.

The sediment was obtained using a Van Veen grab, being packed in plastic bags and kept under refrigeration until arriving in the laboratory. An aliquot of each sediment sample was used for the resuspension test and the remaining material frozen until chemical analysis. The physical-chemical parameters of the superficial water $(\mathrm{pH}$, dissolved oxygen, temperature, salinity and conductivity) were measured at the sampling stations, using a multiparameter YSI model 85 probe. At each sampling station, surface water samples were also collected for total nitrogen and carbon analysis in $50-\mathrm{ml}$ amber glass bottles, previously decontaminated in $10 \% \mathrm{HCl}$ and calcined at $450{ }^{\circ} \mathrm{C}$ for $4 \mathrm{~h}$.

\subsection{Resuspension test}

For the resuspension test, about $6 \mathrm{~L}$ of sub-superficial water was sampled at the outermost sampling station (point 01) in 1-L amber glass bottle, previously decontaminated in $10 \% \mathrm{HCl}$ and calcined. It was carried out at room temperature $\left(25^{\circ} \mathrm{C}\right)$. Wet sediment subsamples $(7.5 \mathrm{~g})$ were transferred to $125-\mathrm{mL}$ Erlenmeyer flask and were shaken in $100 \mathrm{~mL}$ of unfiltered estuarine water in contact with atmosphere. The sediment:water proportion was 
Fig. 1 Localization of Sepetiba Bay and the mouth of São Francisco Channel, showing the three sampling sectors. IS internal sector, with two sampling stations; CS central sector, with six sampling stations; ES external sector, with six sampling stations

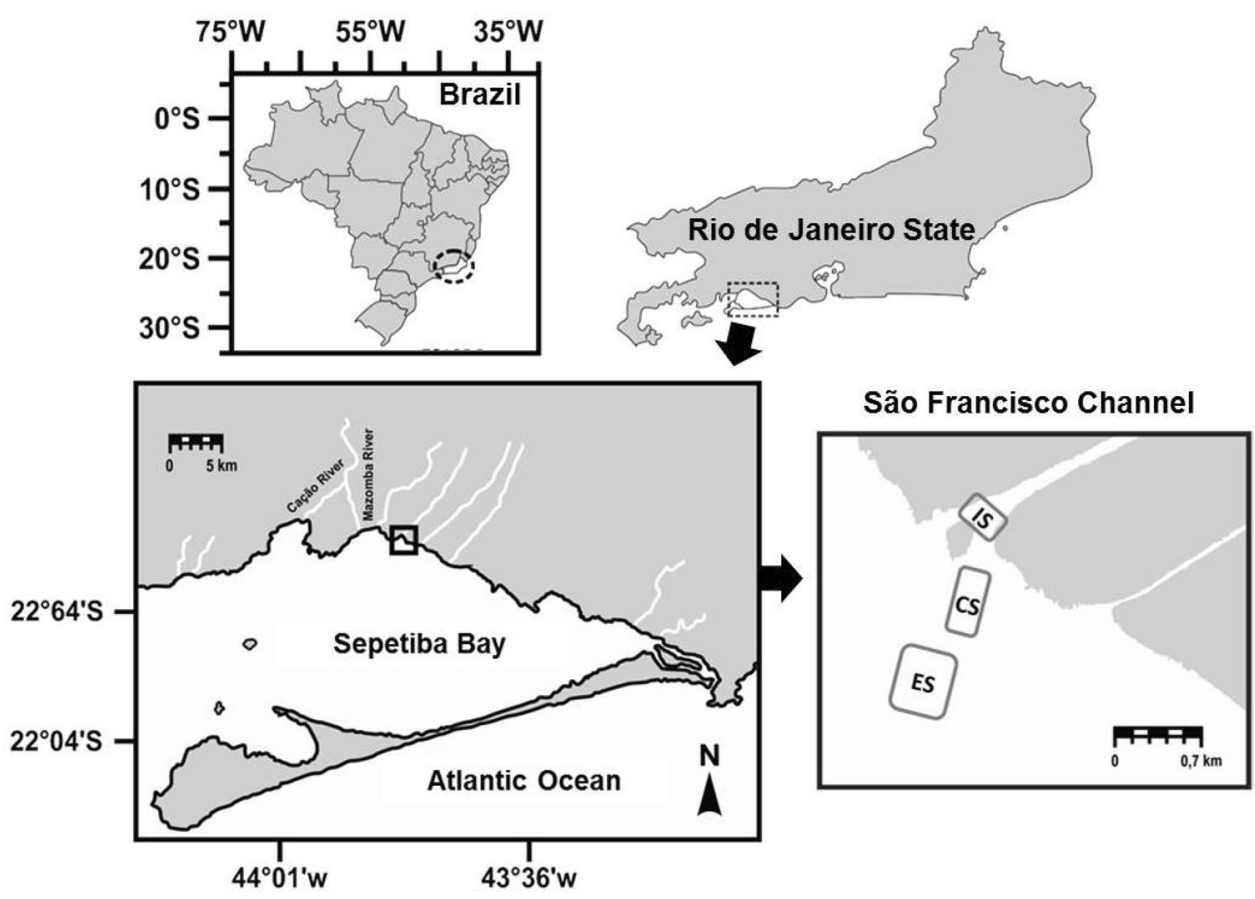

based on the study of Morse [38], adapted by Machado et al. [31]. The experiments compared short ( $1 \mathrm{~h}$ ) and long (24 h) time periods of resuspension. Then, for each sampling station, four Erlenmeyer flasks were prepared, being two of them mechanically shaken during $1 \mathrm{~h}$ (T1) and the other two during $24 \mathrm{~h}$ (T2). Additionally, four Erlenmeyer flasks containing only water were used as blank (two for each time interval of agitation). The choice of these intervals was based on the previous studies, which demonstrated that in the first hour (T1) most bioavailability changes occur [31]. The second interval ( $\mathrm{T} 2: 24 \mathrm{~h}$ ) has been also previously adopted [38] and was used to evaluate the stability of the contaminant response, simulating longer resuspension events, since dredging resuspension of sediments may occur during many hours. The initial condition of all sediment samples and of the water used for the test was evaluated (TO).

After the resuspension test, the physical-chemical parameters of the water were measured (temperature, salinity, dissolved oxygen-OD and $\mathrm{pH}$ ). An aliquot of the water (about $50 \mathrm{~mL}$ ) was vacuum filtered using a decontaminated glass kit and a calcined glass fiber filter with a porosity of $0.22 \mu \mathrm{m}$. These filtered water samples were destined to total carbon and nitrogen analyzes, being stored in amber glass bottles of $50 \mathrm{~mL}$, acidified with boric acid and kept under refrigeration. For sediment separation, the remaining aliquot (mix of sediment and $50 \mathrm{~mL}$ of water) was transferred to a 50-ml Falcon tube and centrifuged at $3000 \mathrm{rpm}$ for $5 \mathrm{~min}$. The supernatant was discarded, and the sediment was dried under $<40^{\circ} \mathrm{C}$ for subsequent homogenization.

\subsection{Chemical analysis}

\subsubsection{Nutrients}

The total carbon (TC) and total nitrogen (NT) in the water samples were obtained by catalytic oxidation under high temperature with a Shimadzu TOC Vcph. For the analysis of the total organic carbon in sediments, previously the carbonate content was removed by acidification (shaken in $1 \mathrm{~mol} \mathrm{~L}^{-1} \mathrm{HCl}$ for $16 \mathrm{~h}$ ). The determination was performed on the Shimadzu TOC-V analyzer using the SSM-5000A module for solids analysis. To certify the equipment calibration, the certified material of potassium hydrogen phthalate (certified concentration of $47.1 \%$ ) was used, obtaining a mean concentration of $51.17 \pm 0.02 \%$, corresponding to a recovery of $108.6 \%$.

The concentrations of total phosphorus were determined in $0.5 \mathrm{~g}$ of dry sediment after calcination $\left(450^{\circ} \mathrm{C} / 4 \mathrm{~h}\right)$. These calcined samples were transferred to Falcon tubes with addition of $10 \mathrm{~mL}$ of $1 \mathrm{~mol} \mathrm{~L}^{-1} \mathrm{HCl}$, being subsequently shaken for $16 \mathrm{~h}$. After stirring, the samples were centrifuged for $20 \mathrm{~min}$ at $2500 \mathrm{rpm}$. After this procedure, the methodology followed the colorimetric method used to determine dissolved orthophosphate (Grasshoff et al. 1983), in a spectrophotometer (Thermo Scientific, model Genesys 10S). In order to obtain inorganic phosphorus, the procedure was performed with non-calcined samples. Organic phosphorus is obtained by the difference of total phosphorus by inorganic phosphorus. At the same time, total phosphorus certified material (PACS-3; $937 \mu \mathrm{g} \mathrm{g}^{-1}$ ) was used, 
obtaining a mean concentration of $907.1 \pm 74.7 \mu \mathrm{g} \mathrm{g}^{-1}$ corresponding to $96.8 \%$ of recovery.

\subsubsection{Bioavailable metals}

To obtain the bioavailable fraction, about $1 \mathrm{~g}$ of dry sediment sample was weighed directly into a $50-\mathrm{mL}$ polypropylene tube (Falcon), where $40 \mathrm{~mL}$ of $1 \mathrm{~mol} \mathrm{~L}^{-1} \mathrm{HCl}$ solution was added. The mixture was stirred for $16 \mathrm{~h}$. Then, the sample was centrifuged ( $3000 \mathrm{rpm} / 5 \mathrm{~min}$ ) and the supernatant filtered (slow filtration, $0.45 \mu \mathrm{m}$ ) and stored in $30-\mathrm{mL}$ acrylic tubes for metals determination $(\mathrm{Cd}, \mathrm{Cr}$ $\mathrm{Cu}, \mathrm{Fe}, \mathrm{Mn}, \mathrm{Ni}, \mathrm{Pb}$ and $\mathrm{Zn}$ ). The extraction was performed for both non-resuspended sediments (T0) and those from the resuspension tests ( $\mathrm{T} 1$ and $\mathrm{T} 2$ ). According to Morse [38], the extraction in $\mathrm{HCl} 1 \mathrm{~mol} \mathrm{~L}^{-1}$ comprises the reactive phase of the metals, that is, the potentially more bioavailable. Huerta-Diaz and Morse [23], Townsend et al. [52], Hatje et al. [20], Machado et al. [31], Peña-Icart et al. [42] and Monte et al. [36] also mention that this extraction is widely used in the determination of the bioavailability of metals in sediments.

The metals determination was performed by inductively coupled plasma optical emission spectrometry (ICP OES) with radial vision, Horiba Jobin Yvon brand, Ultima 2 model (Longjumeau, France), equipped with a cyclonic nebulization chamber, MiraMist nebulizer (Mira Mist CE, Burgener Research Inc., Ontario, Canada), automatic sampler model AS 421 and operational software Analyst 5.4 for data acquisition. For the calibration, solutions of $\mathrm{Cd}, \mathrm{Cu}, \mathrm{Fe}$, $\mathrm{Mn}, \mathrm{Ni}, \mathrm{Pb}$ and $\mathrm{Zn}$ were prepared from the dilution of stock solutions SpecSol of concentration $1000 \mathrm{mg} \mathrm{L}^{-1}$ (Quimlab Chemical, Metrologia ', Jardim California, Jacareí, São Paulo, Brazil), until obtaining the desired concentrations using ultrapure water obtained from an Elga system, PURELAB Ultra Analytic model (Elga, High Wycombe, Bucks, UK). The detection limits were in $\mathrm{mg} \mathrm{kg}^{-1}: 0.01$ for $\mathrm{Cd}, \mathrm{Cu}$ and $\mathrm{Ni} ; 13.0$ for Fe; 0.18 for $\mathrm{Mn} ; 0.02$ for $\mathrm{Pb}$ and $\mathrm{Zn}$.

\subsection{Grain size}

The grain size of the sediment samples was characterized using a particle size analyzer CILAS model 1064, after shaking about $1 \mathrm{~g}$ of wet sample in a dispersing agent (sodium hexametaphosphate $40 \mathrm{~g} \mathrm{~L}^{-1}$ ) for $24 \mathrm{~h}$. The results were analyzed by GRADISTAT 1.0 program.

\subsection{Data treatment}

The statistical treatment of the results was performed on STATISTICA 10.0 (2007 Statsoft Inc.). The Kruskal-Wallis and Mann-Whitney $U$ tests were applied to verify possible differences between groups (between sectors and between resuspension times), in addition to the Spearman correlation $(p<0.05)$, to identify possible relationships between the water and sediment characterization with the geochemical mobility of metals.

\section{Results and discussion}

\subsection{Geochemical characterization}

The mean values of $\mathrm{pH}$, salinity and temperature showed a tendency of increase from the river mouth to the bay (Table 1), ranging from $7.03,0.76$ and $23.7^{\circ} \mathrm{C}$ in the internal sector to $8.01,6,26$ and $25.1^{\circ} \mathrm{C}$ in the external sector, respectively, showing the influence of the water of the bay in the transect. However, only temperature showed significant differences between the external sector and the internal and central sectors (Kruskal-Wallis, $p<0.05$ ), and $\mathrm{pH}$ only showed significant differences between the internal and external sectors (Kruskal-Wallis, $p<0.05$ ). The three sectors showed salinity between 0.5 and 30, allowing to classify the region's water as estuarine (Brazil 2012). Mean values of dissolved oxygen (OD) presented a nonsignificant decrease in the internal sector $\left(7.2 \mathrm{mg} \mathrm{L}^{-1}\right)$ for the external sector $\left(5.4 \mathrm{mg} \mathrm{L}^{-1}\right)$. The values of $\mathrm{pH}$ (between 6.5 and 8.5) and $\mathrm{OD}$ (higher than $5 \mathrm{mg} \mathrm{L}^{-1}$ ) also are within the limits established for estuarine water by CONAMA Resolution 454/12 (Brazil 2012). The mean values of total carbon in water (TC) were $5.5 \mathrm{mg} \mathrm{L}^{-1}$ in the internal sector and increased not significantly up to $6.2 \mathrm{mg} \mathrm{L}^{-1}$ in the external sector. Total nitrogen in water (TN) showed the opposite behavior, higher concentrations in the internal sector $\left(1.1 \mathrm{mg} \mathrm{L}^{-1}\right)$ and lower in the external sector $\left(0.9 \mathrm{mg} \mathrm{L}^{-1}\right)$ (Kruskal-Wallis, $p<0.05$ ). This behavior was also observed by Rodrigues et al. [47] in the same area of the present study and by Brandini et al. [6] in the estuarine area of Iguaçu River, in Guanabara Bay-RJ, Brazil. These authors suggested that the decrease in NT concentration along the saline gradient is related to the increase in primary productivity, where part of the TN is assimilated by biota.

The sediments were classified, mainly, as silty, with more than $90 \%$ of mud (Table 1). The same predominance of the fine fraction was reported previously in Sepetiba Bay by Firmino et al. [18] in the same study area ( $>70 \%)$, by Rodrigues et al. $[46,48,49]$ in Madeira Island ( $>70 \%)$, Monte et al. [36] in Engenho Creek (> 80\%) and Ribeiro et al. [44] in the inner part of the bay. Fine grain sizes such as silt and clay tend to be more reactive due to the higher specific surface, adsorbing metals [51]. In the present study, the silt fraction showed a positive correlation (Spearman, $\mathrm{Cd}=0.62, \mathrm{Cr}=0.75, \mathrm{Cu}=0.80, \mathrm{Fe}=0.79, \mathrm{Mn}=0.64, \mathrm{Ni}=0.84$, $\mathrm{Pb}=0.79, \mathrm{Zn}=0.63, p<0.05$ ) with all metals, indicating this potential of metal retention in fine sediments. 
Table 1 Average \pm standard deviation (minimummaximum) of all studied variables in superficial water and surface sediments of São Francisco Channel, along a small-scale saline gradient (Sepetiba Bay, RJ, Brazil)

\begin{tabular}{|c|c|c|c|}
\hline & Internal & Central & External \\
\hline \multicolumn{4}{|l|}{ Water } \\
\hline Temperature $\left({ }^{\circ} \mathrm{C}\right)$ & $\begin{array}{l}23.7 \pm 0.0 \\
(23.7-23.7)\end{array}$ & $\begin{array}{l}23.8 \pm 0.2 \\
(23.7-24.1)\end{array}$ & $\begin{array}{l}25.1 \pm 0.2 \\
(24.8-25.4)\end{array}$ \\
\hline Salinity & $\begin{array}{l}0.8 \pm 0.1 \\
(0.7-0.8)\end{array}$ & $\begin{array}{l}1.6 \pm 0.5 \\
(0,8-2.1)\end{array}$ & $\begin{array}{l}6.3 \pm 6.9 \\
(0.8-19.7)\end{array}$ \\
\hline $\mathrm{pH}$ & $\begin{array}{l}7.0 \pm 0.2 \\
(6.9-7.2)\end{array}$ & $\begin{array}{l}7.4 \pm 0.3 \\
(7.1-7.9)\end{array}$ & $\begin{array}{l}8.0 \pm 0.3 \\
(7.6-8.4)\end{array}$ \\
\hline $\mathrm{DO}\left(\mathrm{mg} \mathrm{L}^{-1}\right)$ & $\begin{array}{l}7.2 \pm 0.6 \\
(6.8-7.7)\end{array}$ & $\begin{array}{l}6.8 \pm 0.2 \\
(6.5-7.0)\end{array}$ & $\begin{array}{l}5.4 \pm 1.3 \\
(3.8-7.2)\end{array}$ \\
\hline $\mathrm{TC}\left(\mathrm{mg} \mathrm{L}^{-1}\right)$ & $\begin{array}{l}5.5 \pm 1.8 \\
(4.3-6.8)\end{array}$ & $\begin{array}{l}5.7 \pm 1.1 \\
(4.2-6.7)\end{array}$ & $\begin{array}{l}6.2 \pm 1.6 \\
(3.2-7.6)\end{array}$ \\
\hline $\mathrm{TN}\left(\mathrm{mg} \mathrm{L}^{-1}\right)$ & $\begin{array}{l}1.1 \pm 0.0 \\
(1.1-1.1)\end{array}$ & $\begin{array}{l}1.0 \pm 0.0 \\
(1.0-1.0)\end{array}$ & $\begin{array}{l}0.9 \pm 0.2 \\
(0.6-1.1)\end{array}$ \\
\hline \multicolumn{4}{|l|}{ Sediment } \\
\hline Clay (\%) & $\begin{array}{l}13.46 \pm 0.13 \\
(13.37-13.55)\end{array}$ & $\begin{array}{l}31.31 \pm 19.63 \\
(16.22-69.86)\end{array}$ & $\begin{array}{l}18.09 \pm 24.63 \\
(0.00-65.23)\end{array}$ \\
\hline Silt (\%) & $\begin{array}{l}81.72 \pm 0.12 \\
(81.63-81.80)\end{array}$ & $\begin{array}{l}63.75 \pm 17.94 \\
(28.52-77.60)\end{array}$ & $\begin{array}{l}73.09 \pm 20.54 \\
(32.35-87.48)\end{array}$ \\
\hline Sand (\%) & $\begin{array}{l}4.82 \pm 0.01 \\
(4.81-4.83)\end{array}$ & $\begin{array}{l}4.94 \pm 1.77 \\
(1.62-6.18)\end{array}$ & $\begin{array}{l}8.81 \pm 6.65 \\
(2.42-17.60)\end{array}$ \\
\hline TOC (\%) & $\begin{array}{l}2.7 \pm 0.7 \\
(2.3-3.2)\end{array}$ & $\begin{array}{l}1.0 \pm 0.6 \\
(0.4-1.8)\end{array}$ & $\begin{array}{l}1.6 \pm 0.6 \\
(0.6-2.6)\end{array}$ \\
\hline $\operatorname{TP}\left(\mu g g^{-1}\right)$ & $\begin{array}{l}474.9 \pm 138.7 \\
(376.8-573.0)\end{array}$ & $\begin{array}{l}189.5 \pm 67.7 \\
(130.1-282.6)\end{array}$ & $\begin{array}{l}328.1 \pm 131.7 \\
(135.9-513.3)\end{array}$ \\
\hline $\mathrm{OP}\left(\mu \mathrm{g} \mathrm{g}^{-1}\right)$ & $\begin{array}{l}170.4 \pm 44.9 \\
(138.6-202.1)\end{array}$ & $\begin{array}{l}83.2 \pm 31.9 \\
(49.3-134.5)\end{array}$ & $\begin{array}{l}149.3 \pm 50.4 \\
(70.7-218.1)\end{array}$ \\
\hline $\mathrm{IP}\left(\mu \mathrm{g} \mathrm{g}^{-1}\right)$ & $\begin{array}{l}304.6 \pm 93.8 \\
(238.2-370.9)\end{array}$ & $\begin{array}{l}106.3 \pm 39.3 \\
(63.5-150.9)\end{array}$ & $\begin{array}{l}178.9 \pm 81.5 \\
(65.2-295.2)\end{array}$ \\
\hline $\mathrm{Cd}\left(\mathrm{mg} \mathrm{kg}^{-1}\right)$ & $\begin{array}{l}0.32 \pm 0.08 \\
(0.27-0.38)\end{array}$ & $\begin{array}{l}0.17 \pm 0.08 \\
(0.13-0.30)\end{array}$ & $\begin{array}{l}0.57 \pm 0.26 \\
(0.22-1.02)\end{array}$ \\
\hline $\mathrm{Cr}\left(\mathrm{mg} \mathrm{kg}^{-1}\right)$ & $\begin{array}{l}5.97 \pm 1.54 \\
(4.88-7.06)\end{array}$ & $\begin{array}{l}2.81 \pm 0.90 \\
(1.99-4.51)\end{array}$ & $\begin{array}{l}6.37 \pm 2.00 \\
(2.81-8.27)\end{array}$ \\
\hline $\mathrm{Cu}\left(\mathrm{mg} \mathrm{kg}^{-1}\right)$ & $\begin{array}{l}8.99 \pm 2.3 \\
(7.36-10.61)\end{array}$ & $\begin{array}{l}3.43 \pm 1.6 \\
(2.15-6.37)\end{array}$ & $\begin{array}{l}7.20 \pm 2.5 \\
(2.60-10.20)\end{array}$ \\
\hline $\mathrm{Ni}\left(\mathrm{mg} \mathrm{kg}^{-1}\right)$ & $\begin{array}{l}2.39 \pm 0.4 \\
(2.07-2.71)\end{array}$ & $\begin{array}{l}1.07 \pm 1.9 \\
(0.35-1.75)\end{array}$ & $\begin{array}{l}2.06 \pm 0.6 \\
(1.03-2.80)\end{array}$ \\
\hline $\mathrm{Fe}\left(\mathrm{mg} \mathrm{kg}^{-1}\right)$ & $\begin{array}{l}12,597.5 \pm 3124.5 \\
(10,388.17-14,806.83)\end{array}$ & $\begin{array}{l}6013.3 \pm 1278.3 \\
(4836.92-8380.92)\end{array}$ & $\begin{array}{l}9189.1 \pm 2379.7 \\
(5233.91-12,336.31)\end{array}$ \\
\hline $\mathrm{Mn}\left(\mathrm{mg} \mathrm{kg}^{-1}\right)$ & $\begin{array}{l}200.9 \pm 34.2 \\
(176.67-225.10)\end{array}$ & $\begin{array}{l}89.1 \pm 19.5 \\
(60.52-117.09)\end{array}$ & $\begin{array}{l}95.8 \pm 24.9 \\
(46.09-111.29)\end{array}$ \\
\hline $\mathrm{Pb}\left(\mathrm{mg} \mathrm{kg}^{-1}\right)$ & $\begin{array}{l}15.2 \pm 3.1 \\
(13.02-17.39)\end{array}$ & $\begin{array}{l}7.0 \pm 1.9 \\
(5.53-10.67)\end{array}$ & $\begin{array}{l}12.7 \pm 3.6 \\
(5.59-15.66)\end{array}$ \\
\hline $\mathrm{Zn}\left(\mathrm{mg} \mathrm{kg}^{-1}\right)$ & $\begin{array}{l}114.6 \pm 23.8 \\
(97.76-131.45)\end{array}$ & $\begin{array}{l}63.2 \pm 21.6 \\
(27.08-94.36)\end{array}$ & $\begin{array}{l}222.0 \pm 169.0 \\
(85.66-559.11)\end{array}$ \\
\hline
\end{tabular}

$D O$ dissolved oxygen, $T C$ total carbon, $T N$ total nitrogen, TOC total organic carbon, $T P$ total phosphorus, $O P$ organic phosphorus, IP inorganic phosphorus
The mean TOC content in sediments (Table 1) was $1.8 \pm 0.7 \%$. Monte et al. [36] and Rodrigues et al. [46, 48, 49], in studies carried out in Engenho Creek (near the São Francisco Channel), observed TOC contents between $1.7-4.2 \%, 2.4-3.6 \%$ and $1.5-4,3 \%$, respectively, being similar to the present study. Ribeiro et al. [44] also found TOC values similar to the present study (between 2 and 3\%) in
Sepetiba Bay and associated this concentration with the presence of large mangrove extension in the inner portion of the bay, suggesting that these are one important natural source of organic matter. All metals presented positive and significant correlations with TOC (Spearman, $p<0.05$ ), which is widely observed in both recent $[11,33]$ and classical studies [51], where the organic matter is indicated as 
an important mechanism of metals complexation in the sediment.

Borges et al. [5] cite that phosphorus concentrations can be used as an indication of the contribution of domestic effluents. The mean values of total phosphorus (TP), organic phosphorus (OP) and inorganic phosphorus (IP) in sediment were $330.9 \pm 143.2{\mu \mathrm{g} \mathrm{g}^{-1}, 134.3 \pm 54 \mu \mathrm{g} \mathrm{g}}^{-1}$ and $196.6 \pm 92.2 \mathrm{\mu g} \mathrm{g}^{-1}$, respectively, and did not show significant differences among the sectors, except for the PO, which was twice less in the central sector (Kruskal-Wallis, $p<0.05)$. TP, OP and IP values showed a similar trend, with higher concentrations in the internal sector and lower in the central sector (Table 1). Brandini et al. [6] observed the same behavior in a saline gradient on Guanabara Bay and suggested that phosphorus could suffer remineralization by the bacterial community activity along the gradient. Dias (2006) pointed out that in this region of Sepetiba Bay, organic phosphorus could be transformed in exchangeable phosphorus and this geochemical phase can be adsorbed on the surface of oxy-hydroxides of iron (forming the geochemical phase of phosphorus linked to iron compounds-ferric phosphorus). In anoxic conditions, ferric phosphorus is released to interstitial water, when it could be biologically assimilated, precipitated as an authigenic mineral or transported by diffusion or advection. Firmino et al. [18], also in Sepetiba Bay, found much higher TP and IP values in surface sediments $\left(0-5 \mathrm{~cm}, \sim 1100 \mathrm{\mu g} \mathrm{g}^{-1}\right.$ of IP and $\left.1200 \mu^{-1} \mathrm{~g}^{-1} \mathrm{TP}\right)$. Phosphorus concentrations also showed a positive correlation with all metals (Spearman, $p<0.05$ ), with the exception of PI with Cd and Zn. Usually, the increase in nutrients in the estuarine area is related to the existence of anthropic activities, such as domestic sewage and industrial effluents, on the drainage basin. This way, phosphorus concentrations are also used as a chemical indicator of domestic sewage input [5]. According to Barcellos and Lacerda [2], the phosphorus has great importance in the biogeochemical cycling of organic matter, and then, the correlations of the bioavailable metals with both TOC and TP reinforce the influence of the organic matter cycle on metals partitioning.

Significant differences were observed between the central and external sectors for $\mathrm{Cd}(p=0.009), \mathrm{Cr}(p=0.017), \mathrm{Ni}$ $(p=0.047)$ and $\mathrm{Zn}(p=0.007)$ concentrations (Kruskal-Wallis). Although the concentrations of $\mathrm{Fe}, \mathrm{Mn}, \mathrm{Pb}$ and $\mathrm{Cu}$ presented the same trend of decrease in the central sector, there was no significant difference between the sectors. Comparing the concentrations of all metals with the safety limits established by CONAMA Resolution 454/12, Zn was the only metal that exceeded the level 1 limit of this resolution in the external sector with $222 \mathrm{mg} \mathrm{kg}^{-1}$ (CONAMA level $1, \mathrm{Zn}=150 \mathrm{mg} \mathrm{kg}^{-1}$ ). It is necessary to emphasize the importance of this fact, since these concentrations are only a fraction of the total zinc in the sample, evidencing the problem of zinc contamination in Sepetiba Bay. Several studies $[1-3,27,36,41]$ associated the high concentrations of $\mathrm{Zn}$ and $\mathrm{Cd}$ in the sediment, mainly, to the solid residues disposed by Ingá Mercantil Company in the region of Engenho Creek. The influence of this point source could be seen in other areas of the bay, such as our study area, since part of this material could be carried to the São Francisco Channel region through marine currents. This fact could explain the highest concentrations in the external sector. Machado et al. [30], as well as the present study, found a positive correlation between the $\mathrm{Cd}$ and $\mathrm{Zn}$ concentrations (Spearman, 0.94, $p<0.05$ ), which suggests similar source for both metals. However, other sources should be considered. Dornelles [13] observed high concentrations of $\mathrm{Zn}, \mathrm{Cd}, \mathrm{Pb}, \mathrm{Cr}$ and $\mathrm{Fe}$ to the south of the São Francisco and Guandu channels and associated the high values to the effluents from the industrial park located between these channels. Gomes et al. [19] suggest that the high concentrations of $Z n$ are also related to the effluents from the Atlantic Steelworks Company (CSA) located on the São Francisco Channel.

$\mathrm{Cu}$ and $\mathrm{Pb}$ presented the highest concentrations in the internal sector, corroborating with that reported by Rodrigues et al. [46, 48, 49], who mention that these metals can be found in metallurgical waste that reaches this area. A strong correlation between $\mathrm{Cu}$ and $\mathrm{Pb}$ (Spearman, $0.96, p<0.05$ ) was found, as also observed by Rodrigues et al. $[46,48,49]$, reinforcing the idea of similar sources. Loureiro et al. [29] mention that part of the Pb concentrations would be related to the zinc ore processing, since $\mathrm{Cd}$ and $\mathrm{Pb}$ usually occur in lower proportion in structures of minerals rich in Zn. Ferreira et al. [17] observed that $\mathrm{Pb}$ concentrations in Sepetiba Bay vary according to the tide, increasing from the Engenho Creek region to São Francisco Channel. And finally, the inflow of the Guarda River into Sepetiba Bay is considered in the literature as an important source of $\mathrm{Cu}$ and $\mathrm{Pb}$, due to the industrial activities on its drainage basin $[13,40,45]$.

For $\mathrm{Cr}$ and $\mathrm{Ni}$, the highest concentrations were observed in the internal and external sectors (Table 1), with no significant differences between them. Significant differences for these metals were observed only between the central and external sectors (Kruskal-Wallis, $p<0.05$ ). In comparison with the previous works, the bioavailable concentrations of $\mathrm{Ni}$ are higher than the range described by Monte et al. [37] (0.63-1.48 $\left.\mathrm{mg} \mathrm{kg}^{-1}\right)$ - that used the same methodology as the present study_for Engenho Creek; and lower than the described by Rodrigues et al. $[46,48$, 49] (2.43-3.54 mg kg$\left.{ }^{-1}\right)$, that used a stronger extraction (6 mol L ${ }^{-1} \mathrm{HCl}$ extraction), for Itaguaí Harbor, both in the Sepetiba Bay. However, according to these authors, the occurrence of $\mathrm{Ni}$ at the region appears to be natural, being similar to background concentrations. On the other hand, 
the occurrence of high $\mathrm{Cr}$ concentrations at Sepetiba Bay was reported by Dornelles [13], near São Francisco Channel, probably linked to industrial activities in the drainage basin of both São Francisco and Guandu channels.

Fe and $\mathrm{Mn}$, under oxidizing conditions, tend to precipitate in the forms of oxides/hydroxides. This process is known as a metal retention mechanism in contaminated sediments [51]. In the present study, both had higher concentrations in the internal sector $\left(\mathrm{Fe}, 12,597.5 \mathrm{mg} \mathrm{kg}^{-1} ; \mathrm{Mn}\right.$, $200.9 \mathrm{mg} \mathrm{kg}^{-1}$ ) and did not present significant differences among the sectors. Positive correlations between $\mathrm{Fe}, \mathrm{Mn}$ and all trace metals were found (Spearman, $p<0.05$ ). The exception was for Mn concentrations, which did not show significant correlation with $\mathrm{Zn}$ or $\mathrm{Cd}$. These positive correlations suggest that the bioavailable metals were also related to the $\mathrm{Fe}$ and $\mathrm{Mn}$ oxides and hydroxides dynamics, as previously observed by Monte et al. [36] in the Engenho Creek.

\subsection{Resuspension tests}

The physical-chemical characteristics varied after the experiment (Fig. 2), between the T0 (before resuspension) and the two agitation time intervals (T1-1 h and T2-24 h). The temperature decreased (Kruskal-Wallis, $p<0.001$ ) due to the laboratory's internal temperature. The $\mathrm{pH}(p<0.05)$ and dissolved oxygen $(p<0.001)$ decreased in both time intervals in relation to T0. Machado et al. [31] also observed a decrease in $\mathrm{pH}$ after resuspension assays, suggesting that the sulfide oxidation processes upon sediment resuspension can release acidity and consume oxygen, which may contribute to determine these results. Additionally, it is probable that the behavior of these parameters is related to the bacterial action in the organic matter degradation or to the chemical reactions with iron and manganese oxides and hydroxides, which release $\mathrm{H}^{+}$ions into the solution [51].

Despite the decreasing tendency, TOC contents in the sediment and TC concentrations in the water were not significantly different from T0 (Fig. 3). This behavior may also be related to the action of the bacteria in the degradation of organic matter. The concentrations of total nitrogen in water oscillated after resuspension, but they were not significantly different from T0. The total phosphorus (Kruskal-Wallis, $p<0.05$ ), organic phosphorus (Kruskal-Wallis, $p<0.01$ ) and inorganic phosphorus (Kruskal-Wallis, $p<0.005$ ) increased after both resuspension intervals, suggesting that the organic matter degradation induced by the sediment resuspension would be able to release nutrients such as phosphorus and nitrogen to the water.

Initially, when comparing all the sectors (internal, central and external) with the time intervals (T0, T1 and T2), one can observe significant differences in $\mathrm{Cr}, \mathrm{Fe}, \mathrm{Mn}, \mathrm{Ni}$ and $\mathrm{Pb}$ in $\mathrm{T} 1$ in relation to $\mathrm{T0}$ and in the $\mathrm{Cr}, \mathrm{Cu} \mathrm{Fe} \mathrm{Mn}, \mathrm{Ni}$, $\mathrm{Pb}$ and $\mathrm{Zn}$ in T2 (Mann-Whitney $U$ test; $p<0.05$ ). Few differences on the bioavailability of metals behavior after resuspension were found, considering the sectors individually. For example, interval T1 in relation to T0, significant differences were also observed in temperature and $\mathrm{Zn}$ in the external sector and in temperature, $\mathrm{Zn}$ and $\mathrm{Cd}$ in the central sector. And in the interval $\mathrm{T} 2$ in relation to T0, only the $\mathrm{Cd}$ showed significant differences in the central sector.

The average values for the concentrations of all metals $\left(\mathrm{mg} \mathrm{kg}^{-1}\right.$ ) before resuspension (T0) and after $1 \mathrm{~h}(\mathrm{~T} 1)$ and 24 (T2) resuspension were below the lower limit of resolution CONAMA 454/2012 to sediments of saline/ estuarine areas, with the exception of zinc ( $Z n)$ in the external sector (>150 $\mathrm{mg} \mathrm{kg}^{-1}$ ) (Fig. 4). It is emphasized that the concentrations of the present study metals were determined by a weaker extraction method $\left(\mathrm{HCl} 1 \mathrm{~mol} \mathrm{~L}^{-1}\right)$ than the suggested in CONAMA 454/2012 for dredged sediments (3051A USEPA); consequently, the described concentrations represent an even greater risk to biota. After resuspension, the $\mathrm{Zn}$ concentration increased from 222 to $316.2 \mathrm{mg} \mathrm{kg}^{-1}$ at T2 (Kruskal-Wallis, $p<0.05$ ) in the external sector, possibly because this sector presents the most oxidizing condition. The $\mathrm{Zn}$ concentrations are
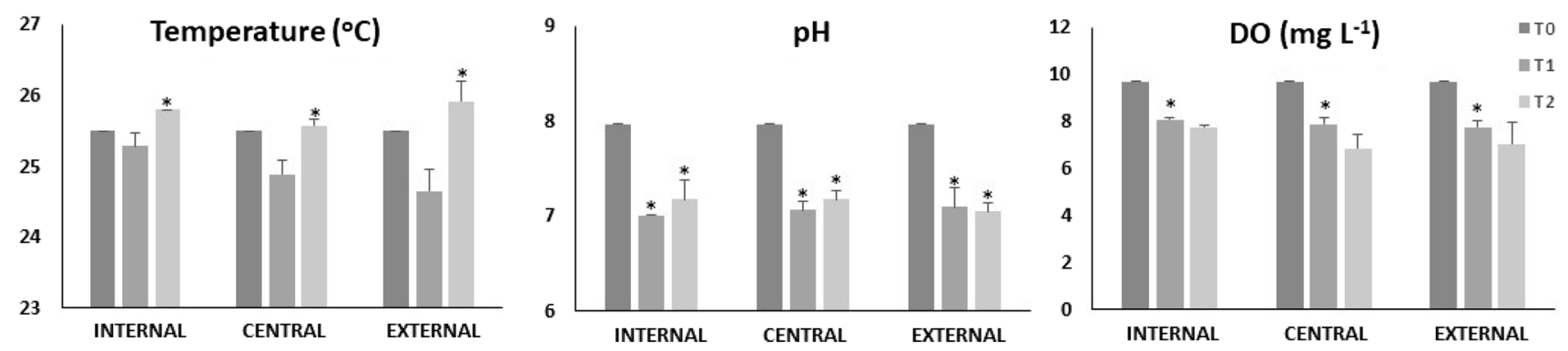

Fig. 2 Average \pm standard deviation of the water physical-chemical parameters (temperature, $\mathrm{pH}$ and dissolved oxygen-DO) before resuspension (T0) and after $1 \mathrm{~h}(\mathrm{~T} 1)$ and $24 \mathrm{~h}(\mathrm{~T} 2)$ of resuspension of sediments from three sectors of the saline gradient of São Francisco Channel. *Significantly different of T0 $(p<0.05)$ 
Fig. 3 Average \pm standard deviation of total carbon (TC) and total nitrogen (TN) in water and of the total organic carbon (TOC), total phosphorus (TP), organic phosphorus (OP) and inorganic phosphorus (IP) in sediments, before resuspension (T0) and after $1 \mathrm{~h}$ (T1) and $24 \mathrm{~h}$ (T2) of resuspension of sediments from three sectors of the saline gradient of São Francisco Channel. *Significantly different of T0 $(p<0.05)$

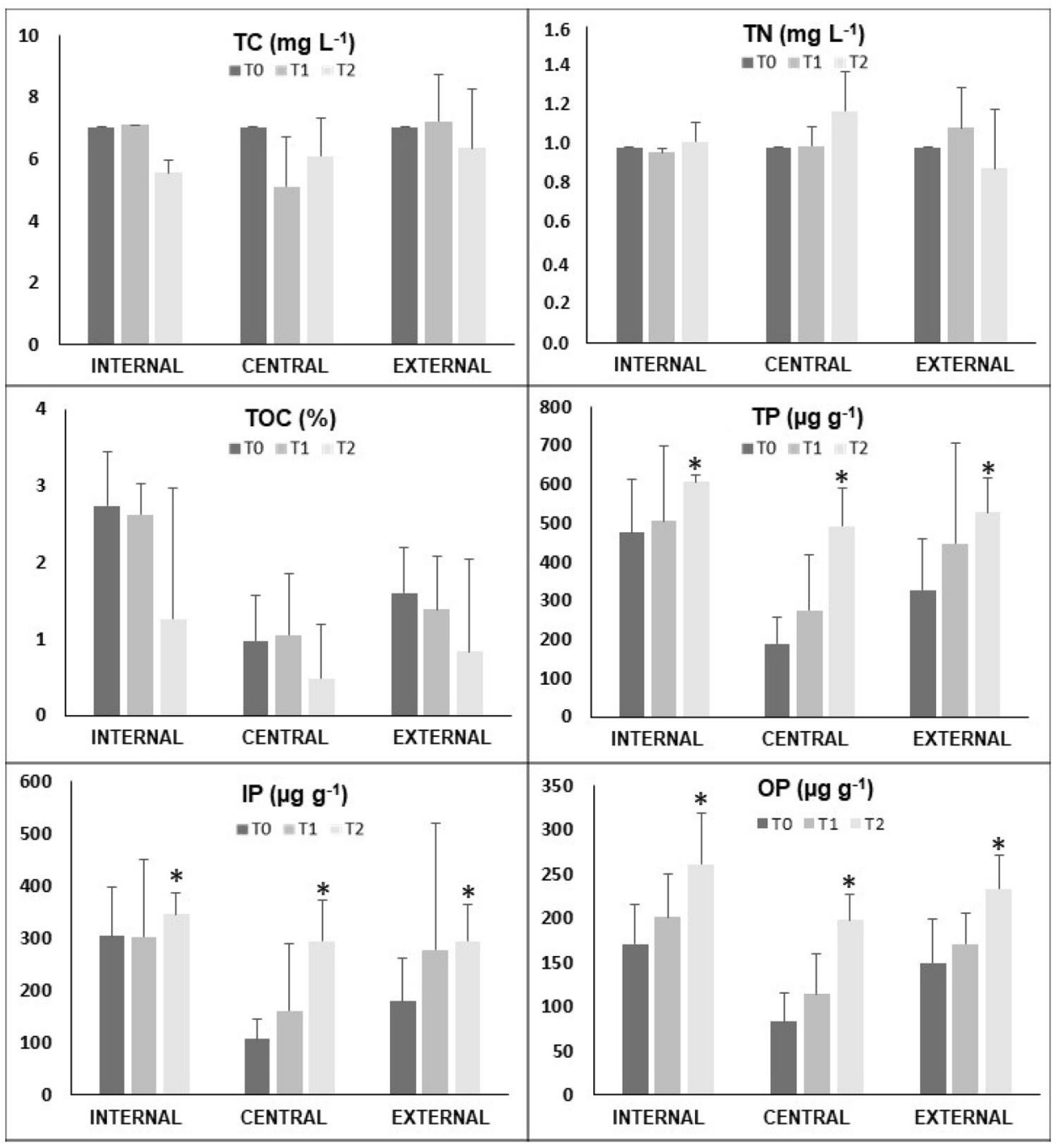

correlated with Cd (T1-0.94; T2-0.90), Pb (T1-0.78 T2-0.66), $\mathrm{Ni}(\mathrm{T} 1-0.78, \mathrm{~T} 2-0.67), \mathrm{Cr}$ (T1-0.89, T2-0.89) and Cu (T1-0.66), suggesting that these metals presented similar behavior after resuspension. Besides correlations among metals, the $Z n$ contents in bioavailable phase were correlated to OP $(0.56, p<0.05)$, temperature $(0.62, p<0.05)$ and TN $(-0.66$, $p<0.05)$. Similarly to $\mathrm{Zn}, \mathrm{Cd}$ concentrations were also greater in the external sector but there were no significant differences between the time intervals. In addition, the $\mathrm{Cd}$ presented the same correlations with the physical-chemical characteristics and the metals as the Zn, what corroborate the hypothesis of the influence of the geochemical characteristics on metals mobility.

$\mathrm{Cu}$ and $\mathrm{Pb}$ presented the same behavior, an increase in the mean concentrations of both in T1 and even higher in T2 when compared to T0 (Kruskal-Wallis, $p<0.001$ ). There was a strong correlation between these metals at the two intervals (Spearman, 0.95 at T1 and 0.82 at T2, $p<0.05$ ). With the physical-chemical characteristics, both presented correlations with TOC (Cu: 0.86; Pb: 0.76, $p<0.05)$ and with
OP (Cu: 0.96; Pb: 0.87, $p<0.05$ ) in T1. In T2, both had negative correlation with TN in water (Cu: -0.78 ; $\mathrm{Pb}:-0.90$, $p<0.05)$ and with $\mathrm{pH}(\mathrm{Cu}:-0.80$ and $\mathrm{Pb}:-0.68 ;<0.05)$. In general, metals are more bioavailable in lower $\mathrm{pH}$ conditions [31]. The Ni concentrations increased in T1 (Kruskal-Wallis, $p<0.01$ ) and T2 (Kruskal-Wallis, $p<0.05$ ). On the other hand, $\mathrm{Cr}$ concentrations were similar along the experiment. Both metals were correlated to OP $(\mathrm{Cr}$ : 0.67 and $\mathrm{Ni}$ : 0.78). Also, Ni presented correlation with TOC (0.55) in T1 and $\mathrm{Cr}$ with $\mathrm{pH}(-0.59)$ and TN (-0.84) in T2.

The behavior of iron (Fe) and manganese (Mn) was similar across sectors, where both metals had the highest average concentrations in the internal sector in the three time intervals (T0, T1 and T2); it was observed that there was an increase in the mean concentrations after $1 \mathrm{~h}$ of agitation and, even more after $24 \mathrm{~h}$ of agitation in relation to the T0 (Kruskal-Wallis, $p<0.001$ ). The positive correlations of Fe with all metals in the interval $\mathrm{T} 1(\mathrm{Cd}=0.59$, $\mathrm{Cr}=0.74, \mathrm{Cu}=0.88, \mathrm{Mn}=0.55, \mathrm{Ni}=0.83, \mathrm{~Pb}=0.82$ and $\mathrm{Zn}=0.54, p<0.05)$, together with the decrease in $\mathrm{pH}$ and 
Fig. 4 Average \pm standard deviation of metals' concentrations on bioavailable in sediments, before resuspension (T0) and after $1 \mathrm{~h}(\mathrm{~T} 1)$ and $24 \mathrm{~h}(\mathrm{~T} 2)$ of resuspension of sediments from three sectors of the saline gradient of São Francisco Channel. *Significantly different of T0 $(p<0.05)$. The dotted line represents the safety limit for aquatic biota according to CONAMA Resolution 454/12 and ERL $\left(\mathrm{Zn}=150 \mathrm{mg} \mathrm{kg}^{-1}\right)$

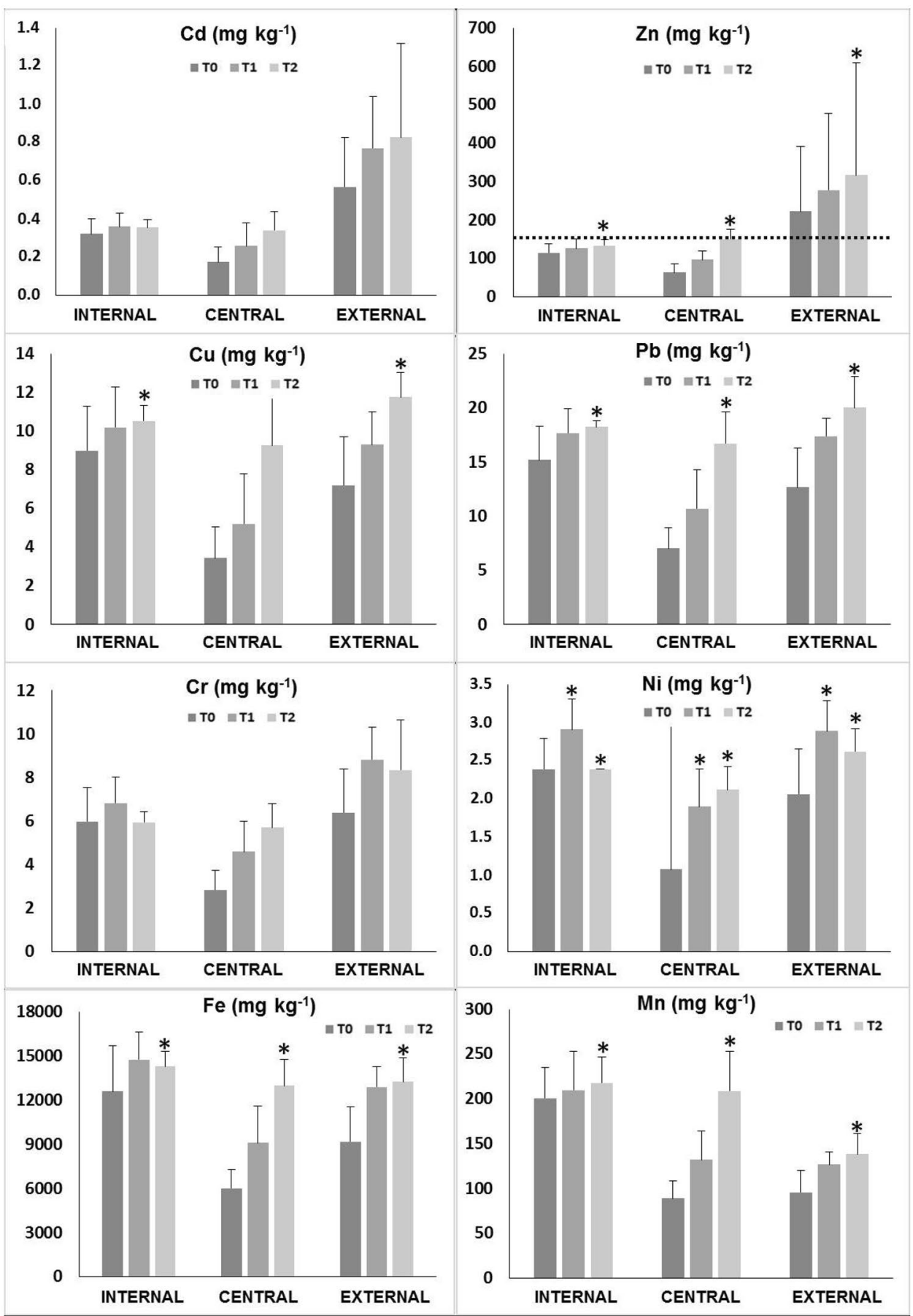

DO, could increase Fe in solution, releasing trace metals to a bioavailable phase. $\mathrm{Mn}$ only showed Cu correlation in the $\mathrm{T} 1$ interval $(0.59 ; p<0.05)$.

In general, the resuspension experiment indicated an increase in bioavailable metals' concentrations (Table 2) in the first hour at the three sectors. Slightly changes were found for $\mathrm{Mn}$ in the internal sector (increase of $4.5 \%$ ), while for $\mathrm{Ni}$ in the central sector the increase was of $76.4 \%$. This increase in $\mathrm{Ni}$ in the central sector seemed to be linked to the decrease in DO (Spearman, $p<0.05)$ and the fine grain content (Spearman, $p<0.05$ ). After $24 \mathrm{~h}$ of resuspension, the samples from the external sector showed the same tendency of increase, with an increment of $30-60 \%$ on metals' concentrations in the bioavailable fraction. However, the internal sector, continued to have unexpressive changes ( -0.8 to $19.9 \%)$.

At the central sector, all metals' concentrations were at least twice higher in comparison to the initial 
Table 2 The percentage of gains (+) and losses (-) of $C d$, $\mathrm{Cr}, \mathrm{Cu}, \mathrm{Fe}, \mathrm{Mn}, \mathrm{Ni}, \mathrm{Pb}$ and $\mathrm{Zn}$ on bioavailable geochemical phase after $1 \mathrm{~h}$ and $24 \mathrm{~h}$ of resuspension of surface sediments from São Francisco Channel, Sepetiba Bay-RJ

\begin{tabular}{|c|c|c|c|c|c|c|}
\hline & \multicolumn{2}{|l|}{ Internal } & \multicolumn{2}{|l|}{ Central } & \multicolumn{2}{|l|}{ External } \\
\hline & $\% 1 \mathrm{~h}$ & $\% 24 \mathrm{~h}$ & $\% 1 \mathrm{~h}$ & $\% 24 \mathrm{~h}$ & $\% 1 \mathrm{~h}$ & $\% 24 \mathrm{~h}$ \\
\hline & Internal & & Central & & External & \\
\hline $\mathrm{Cd}$ & 11.3 & 10.1 & 48.8 & 96.3 & 35.7 & 45.9 \\
\hline $\mathrm{Cr}$ & 14.0 & -0.8 & 62.9 & 102.0 & 38.2 & 30.6 \\
\hline $\mathrm{Cu}$ & 13.3 & 17.0 & 51.8 & 170.2 & 29.0 & 63.1 \\
\hline $\mathrm{Fe}$ & 17.1 & 13.5 & 51.4 & 116.1 & 40.4 & 44.1 \\
\hline $\mathrm{Mn}$ & 4.5 & 8.5 & 48.3 & 134.4 & 32.2 & 44.4 \\
\hline $\mathrm{Ni}$ & 21.9 & -0.2 & 76.4 & 97.2 & 40.5 & 27.4 \\
\hline $\mathrm{Pb}$ & 16.4 & 19.9 & 52.5 & 138.4 & 37.1 & 58.0 \\
\hline $\mathrm{Zn}$ & 10.3 & 16.7 & 53.6 & 137.7 & 25.2 & 42.4 \\
\hline Scale & Increase in bioavailability & & & Decrease in bioavailability & & \\
\hline & $0-15 \%=$ none or low & & & 0 to $-15 \%=$ none or low & & \\
\hline & $15-50 \%=$ moderate & & & -15 to $-50 \%=$ moderate & & \\
\hline & $50-100 \%=$ considerable & & & -50 to $-100 \%=$ considerable & & \\
\hline & $>100 \%=$ very high & & & $<-100 \%=$ very high & & \\
\hline
\end{tabular}

concentrations (TO). These samples presented the most important differences on the bioavailability of metals after resuspension, may be due to their physical-chemical characteristics, since before resuspension, all metals were correlated to TOC and/or phosphorus and/or Fe contents (Spearman, $p<0.05$ ). Another characteristic that may influence on metals dynamics on the central sector is the contents of sulfides, known as complexing agents, binding metals on anoxic sediments. Acid volatile sulfides (AVS) concentrations described by different authors vary from $455 \mathrm{mg} \mathrm{kg}^{-1}$ at 2003 [43] to $1.6-5116.0 \mathrm{mg} \mathrm{kg}^{-1}$ at 2012 $[46,48,49]$. Even with high AVS concentrations in some sampling stations, the potential ecological risks associated with metals exposure in sediment of this region are classified as unsure, considering the AVS modeling $[46,48,49]$, which means that the sum of metals' concentrations are higher than the AVS content in the sediment. After resuspension, the oxidation of sulfides could release metals to dissolved phase, as observed by Di Toro et al. [12]. Additionally, the dynamics of Fe and Mn oxides and hydroxides seemed to be an important regulator of bioavailable metals for this area. Monte et al. [36] described strong positive correlations between $\mathrm{Fe}, \mathrm{Cd}$ and $\mathrm{Zn}$ after $1 \mathrm{~h}$ and $24 \mathrm{~h}$ of resuspension of surface sediments from Saco do Engenho Creek, at Sepetiba Bay. Saco do Engenho Creek is only $3.5 \mathrm{~km}$ far from São Francisco Channel, the object of the present study and they presented the same tendency.

The $\mathrm{Cu}$ concentrations increased $170.2 \%$, and this expressive change could be related to the lower $\mathrm{pH}$ after $24 \mathrm{~h}$ of resuspension (Spearman, $p<0.05$ ). This increase is in agreement with another findings described by Machado and coworkers [31], which evaluated the geochemical behavior of $\mathrm{Cu}$ in sediments from Guanabara Bay-RJ (Brazil), by Monte and coworkers [37], for sediments from
Sepetiba Bay-RJ (Brazil) and by Morse [38], in experiments with sediments from Galveston Bay (Texas, USA), where the oxidative process of authigenic sedimentary pyrite was responsible for $\mathrm{As}, \mathrm{Hg}$ and $\mathrm{Cu}$ release.

\section{Conclusion}

It was verified that all the studied metals $(\mathrm{Cd}, \mathrm{Cu}, \mathrm{Fe}, \mathrm{Mn}$, $\mathrm{Pb}$ and $\mathrm{Zn}$ ) presented higher concentrations in the bioavailable phase after being submitted to the resuspension tests, indicating that they have high potential bioavailability, causing possible damages to local biota during dredging activities. The mobility seemed to be more expressive on the samples from the central sector, where TOC and phosphorus contents are lower on the sediments. Also the expressive changes on Fe and $\mathrm{Mn}$ dynamics after resuspension could be responsible for the release of toxic metals to the bioavailable phase at this sector. Changes on mobility were observed since the first hour of experiment, which is important information to environmental management of risks associated with anthropogenic activities that cause resuspension of sediments. These changes on bioavailable metals' concentrations are able to increase ecological risks, especially for $\mathrm{Zn}$, which overcome the safety criteria for aquatic biota. Studies on the potential mobility of metals in coastal regions should be intensified as they contribute to the creation/improvement of environmental policies and, consequently, improvements in the environmental quality of the ecosystem.

Acknowledgements The authors want to thank the Rio de Janeiro State Research Foundation (FAPERJ), for APQ1 assistance (Case Number E-26/111-473/2011); to the National Research Council (CNPq), for 
the financial support of the project (Process Number 481898/20123); and the Coordination for the Improvement of Higher Education Personnel, for the scholarship granted to DSC. A.P.C. Rodrigues.

\section{Compliance with ethical standards}

Conflict of interest On behalf of all authors, the corresponding author states that there is no conflict of interest.

\section{References}

1. Araújo DF, Boaventura GR, Machado W, Viers J, Weiss D, Patchineelam SR, Ruiz I, Rodrigues APC, Babinski M, Dantas E (2017) Tracing of anthropogenic zinc sources in coastal environments using stable isotope composition. Chem Geol. https:// doi.org/10.1016/j.chemgeo.2016.12.004

2. Barcellos C, Lacerda LD (1994) Cadmium and zinc source assessment in the Sepetiba bay na basin region. Environ Monit Assess (Dordrech Online) 29:183-199

3. Barcellos C, Rezende CE, Pfeiffer WC (1991) Zn and Cd production and pollution in a Brazilian coastal region. Mar Pollut Bull 22(11):558-561. https://doi.org/10.1016/0025-326X(91)90896 $-Z$

4. Bennett JR (1987) The physics of sediment transport, resuspension and deposition. Hydrobiologia 149:5-12

5. Borges AC, Sanders CJ, Santos HLR, Araripe DR, Machado W, Patchineelam SR (2009) Eutrophication history of Guanabara Bay (SE Brazil) recorded by phosphorus flux to sediments from a degraded mangrove area. Mar Pollut Bull 58(11):1750-1754. https://doi.org/10.1016/j.marpolbul.2009.07.025

6. Brandini N, Rodrigues APC, Abreu IM, Junior LCC, Knoppers BA, Machado W (2016) Nutrient behavior in a highly-eutrophicated tropical estuarine system. Acta Limnol Bras. https://doi. org/10.1590/S2179-975X3416

7. Brazil (2012) CONAMA Resolution $n^{\circ} 454 / 2012$. Publication on the Daily of the Official Union. https://doi.org/10.1073/ pnas.0703993104

8. Calmano W, Forstner U (1983) Chemical extraction of heavy metals in polluted river sediments in Central Europe. Sci Total Environ 28:77-90

9. Cantwell MG, Burgess RM, King JW (2008) Resuspension of contaminated field and formulated reference sediments part I: evaluation of metal release under controlled laboratory conditions. Chemosphere 73(11):1824-1831. https://doi.org/10.1016/j. chemosphere.2008.08.007

10. Cotou E, Gremare A, Charles F, Hatzianestis I, Sklivagou E (2005) Potential toxicity of resuspended particulate matter and sediments: environmental samples from the Bay of Banyuls-sur-Mer and Thermaikos Gulf. Cont Shelf Res 25(19-20):2521-2532. https ://doi.org/10.1016/J.CSR.2005.08.005

11. Covelli S, Protopsalti I, Acquavita A, Sperle M, Bonardi M, Emili A (2012) Spatial variation, speciation and sedimentary records of mercury in the Guanabara Bay (Rio de Janeiro, Brazil). Cont Shelf Res 35:29-42. https://doi.org/10.1016/j.csr.2011.12.003

12. Di Toro D, Mahony JD, Hansen DJ, Scott KJ, Hicks MB, Mayr SM, Redmond MS (1990) Toxicity of cadmium in sediments: the role of acid volatile sulfide. Environ Toxicol Chem 9:1487-1502

13. Dornelles LMA (2011) Monitoramento de metais pesados na Baía de Sepetiba-RJ-Brasil, com base em geoprocessamento, vol 1. Editora Edgard Blucher Ltda, São Paulo

14. Dropo IG, Ongley ED (1994) Flocculation of suspended sediment in rivers of southeastern Canada. Water Res 28(8):1799-1809
15. Eckert JM, Sholkovitz ER (1976) The flocculation of iron, aluminium and humates from river water by electrolytes. Geochim Cosmochim Acta 40:847-848

16. Fathollahzadeh H, Kaczala F, Bhatnagar A, Hogland W (2015) Significance of environmental dredging on metal mobility from contaminated sediments in the Oskarshamn Harbor, Sweden. Chemosphere 119:445-451. https://doi.org/10.1016/j.chemo sphere.2014.07.008

17. Ferreira $M M$, Araújo $C L$, Patchineelam $S R$, Araripe $D R$, Itabirano JAP, Oliveira MA (2011) Estimativa dos fluxos de $\mathrm{Zn}, \mathrm{Cd}, \mathrm{Pb}, \mathrm{Cu}$ no saco do Engenho, Baía de Sepetiba, RJ. In: XIII Congresso Brasileiro de Geoquímica/III Simpósio de Geoquímica dos Países do Mercosul, Gramado-RS, pp 179-182

18. Firmino ARDS, Rodrigues SK, Ferreira LJS, Vinzon SB, Rodrigues APC, Machado W (2017) Observações preliminares sobre a biogeoquímica do fósforo perfis sedimentares da Baía de SepetibaRJ. In: XVI Congresso Brasileiro de Geoquímica, Búzios-RJ, pp 3-10

19. Gomes FC, Godoy JM, Godoy MLDP, Lara de Carvalho Z, TadeuLopes R, Sanchez-Cabeza JA, Lacerda LD, Wasserman JC (2009) Metal concentrations, fluxes, inventories and chronologies in sediments from Sepetiba and Ribeira Bays: a comparative study. Mar Pollut Bull 59(4-7):123-133. https://doi.org/10.1016/j. marpolbul.2009.03.015

20. Hatje V, Costa LM, Korn MGA, Cotrim G (2009) Speeding up $\mathrm{HCl}$ extractions by employing ultrasound energy to evaluate trace elements bioavailability in sediments. J Braz Chem Soc 20(5):846-852. https://doi.org/10.1590/S0103-5053200900 0500007

21. Herms F, Gurgel MH (2012) Distribuição espacial de metais pesados nos sedimentos da baía de Sepetiba, RJ. In: Rodrigues MAC, Pereira SD, Santos SB (eds) Baía de Sepetiba - Estado da Arte. Corbã, Rio de Janeiro, pp 151-177

22. Herms F, Lanzillotta HAA (2012) Influência de atividades industriais na poluição por metais no rio Guandú, baía de Sepetiba-RJ. In: Filho DT, Antunes JCO, Vettorazzi J (eds) Bacia Hidrográfica dos Rios Guandú, Guarda e Guandú Mirim: Experências para a Gestão dos Recursos Hídricos. Instituto Estadual do Ambiente do Rio de Janeiro-INEA, Rio de Janeiro, pp 180-213

23. Huerta-Diaz MA, Morse JW (1992) Pyritization of trace metals in anoxic marine sediments. Geochim Cosmochim Acta $56: 2681-2702$

24. Instituto Brasileiro de Geografia e Estatística (IBGE) (2013) Censo Demográfico 2010. Technical report, Brazilian Institute of Geography and Statistics. https://censo2010.ibge.gov.br/sinopse/ index.php?dados $=1$ \&uf $=33$. Accessed 18 Aug 2018

25. Kalnejais LH, Martin WR, Bothner MH (2010) The release of dissolved nutrients and metals from coastal sediments due to resuspension. Mar Chem 121(1-4):224-235. https://doi. org/10.1016/j.marchem.2010.05.002

26. Kim EH, Mason RP, Porter ET, Soulen HL (2006) The impact of resuspension on sediment mercury dynamics, and methylmercury production and fate: a mesocosm study. Mar Chem 102(34):300-315. https://doi.org/10.1016/j.marchem.2006.05.006

27. Lacerda LD, Pfeiffer WC, Fiszman M (1987) Heavy metal distribution, availability and fate in Sepetiba Bay, S.E. Brazil. Sci Total Environ 65(C):163-173. https://doi.org/10.1016/00489697(87)90169-0

28. Long ER, Macdonald DD, Smith SL, Calder FD (1995) Incidence of adverse biological effects within ranges of chemical concentrations in marine and estuarine sediments. Environ Manag 19:81-97

29. Loureiro DD, Torotza J, Herms F (2003) Distribuição espacial de metais pesados no sedimento superficial da baía de Sepetiba, RJ. In: IX Congresso da Associação Brasileira de Estudos do Quaternário/II Congresso do Quaternário de Países de Línguas 
Ibéricas/ll Congresso sobre Planejamento e Gestão da Zona Costeira dos Países de Expressão Portuguesa. Recife-PE, pp $10-14$

30. Machado W, Santelli RE, Carvalho MF, Molisani MM, Barreto RC, Lacerda LD (2008) Relation of reactive sulfides with organic carbon, iron, and manganese in anaerobic mangrove sediments: implications for sediment suitability to trap trace metals. J Coast Res 4:25-32. https://doi.org/10.2112/06-0736.1

31. Machado W, Rodrigues APC, Bidone ED, Sella SM, Santelli RE (2011) Evaluation of Cu potential bioavailability changes upon coastal sediment resuspension: an example on how to improve the assessment of sediment dredging environmental risks. Environ Sci Pollut Res. https://doi.org/10.1007/s11356-011-0517-1

32. Maddock JEL, Carvalho MF, Santelli RE, Machado W (2007) Contaminant metal behaviour during re-suspension of sulphidic estuarine sediments. Water Air Soil Pollut 181(1-4):193-200. https://doi.org/10.1007/s11270-006-9290-z

33. Merritt KA, Amirbahman A (2007) Mercury dynamics in sulfiderich sediments: geochemical influence on contaminant mobilization within the Penobscot River estuary, Maine, USA. Geochim Cosmochim Acta 71(4):929-941. https://doi.org/10.1016/j. gca.2006.10.012

34. Molisani MM, Marins RV, Machado W, Paraquetti HHM, Bidone ED, Lacerda LD (2004) Environmental changes in Sepetiba Bay, SE Brazil. Reg Environ Change 4(1):17-27. https://doi. org/10.1007/s10113-003-0060-9

35. Molisani MM, Kjerfve B, Silva AP, Lacerda LD (2006) Water discharge and sediment load to Sepetiba Bay from an anthropogenically-altered drainage basin, SE Brazil. J Hydrol 331(34):425-433. https://doi.org/10.1016/j.jhydrol.2006.05.038

36. Monte CN, Rodrigues APC, Cordeiro RC, Freire AS, Santelli RE, Machado W (2015) Changes in Cd and Zn bioavailability upon an experimental resuspension of highly contaminated coastal sediments from a tropical estuary. Sustain Water Resour Manag 1:335-342. https://doi.org/10.1007/s40899-015-0034-3

37. Monte CN, Rodrigues APC, Freitas AR, Cordeiro RC, Santelli RE, Machado W (2018) Fatores que afetam a biodisponibilidade de contaminantes metálicos em sedimentos superficiais da Baía de Sepetiba, Rio de Janeiro, Brasil. In: Gomes IA (ed) Fins da Geologia, vol 1, 1st edn. Atena, Ponta Grossa, pp 43-57

38. Morse JW (1994) Interactions of trace metals with authigenic sulfide minerals: implications for their bioavailability. Mar Chem 46(1-2):1-6. https://doi.org/10.1016/0304-4203(94)90040-X

39. Pais I, Jones JR (1997) The handbook of trace elements. St. Lucie Press, Boca Raton

40. Patchineelam SR, Leitão-Filho CM, Azevedo FV, Monteiro EA (1989) Variation in the distribution of heavy metals in surface sediments of Sepetiba Bay: Rio de Janeiro, Brazil. In: CEP consultants, heavy metals in the environment. Edinburgh, pp 547-551

41. Pellegatti F, Figueiredo AMG, Wasserman JC (2001) Neutron activation analysis applied to determination of heavy metals and other trace elements in sediments from Sepetiba Bay (RJ). J Geostand Geoanal 25(2-3):307-315

42. Peña-Icart $M$, Mendiguchía $C$, Villanueva-Tagle ME, PomaresAlfonso MS, Moreno C (2014) Revisiting methods for the determination of bioavailable metals in coastal sediments. Mar Pollut Bull 89(1-2):67-74. https://doi.org/10.1016/j.marpo Ibul.2014.10.034

43. Ribeiro AP (2006) Procedimento de fracionamento comparado a modelo de atenuação para a avaliação de mobilidade de metais pesados em sedimentos da Baía de Sepetiba, Rio de Janeiro. Doutorado. Universidade de São Paulo - USP

44. Ribeiro AP, Figueiredo AMG, Santos JO, Dantas E, Cotrim MEB, Figueira RCL, Filho EVS, Wasserman JC (2013) Combined SEM/ AVS and attenuation of concentration models for the assessment of bioavailability and mobility of metals in sediments of Sepetiba Bay (SE Brazil). Mar Pollut Bull 68(1-2):55-63. https:// doi.org/10.1016/j.marpolbul.2012.12.023

45. Rocha DS, Cunha BCA, Geraldes MC, Pereira SD (2012) Metais pesados analisados em sedimentos da baia de Sepetiba: comparação de extração por lixiviação versus dissolução total. In: Rodrigues MAC, Pereira SD, Santos SB (eds) Baía de Sepetiba - Estado da Arte. Corbã, Rio de Janeiro, pp 181-193

46. Rodrigues APC, Monte C, Pereira M, Quaresma TLS, Pova R, Vieira TC, Diaz RA, Moreira M, Machado W (2017) Potential bioavailability of metals in coastal sediments from Sepetiba and Guanabara Bays - RJ, Brazil. In: XIV Congresso de Geoquímica dos Países de Língua Portuguesa, Vila Real, Portugal

47. Rodrigues RP, Knoppers BA, De Souza WFL, Santos ES (2009) Suspended matter and nutrient gradients of a small-scale river plume in Sepetiba Bay, SE-Brazil. Braz Arch Biol Technol 52(2):503-512. https://doi.org/10.1590/S1516-8913200900 0200030

48. Rodrigues APC, Lemos AP, Monte CN, Cesar RG, Machado W (2017) Environmental risk in a coastal zone of Rio de Janeiro State (Brazil) due to dredging activities. In: Araújo CVM, Shinn $\mathrm{CH}$ (eds) Ecotoxicology in Latin America, vol 1, 1st edn. Nova Publishers, Nova lorque, pp 183-200

49. Rodrigues SK, Abessa DMS, Rodrigues APC, Soares-Gomes A, Freitas CB, Santelli RE, Freire AS, Machado W (2017) Sediment quality in a metal-contaminated tropical bay assessed with a multiple lines of evidence approach. Environ Pollut 228(265276):228. https://doi.org/10.1016/j.envpol.2017.05.045

50. Roncarati H, Carelli SG (2012) Considerações sobre o estado da arte dos processos geológicos cenozóicos atuantes na Baía de Sepetiba. In: Rodrigues MAC, Pereira SD, Santos SB (Org.), Baía de Sepetiba - Estado da Arte. Corbã, Rio de Janeiro, pp 13-36

51. Salomons W, Förstner U (1984) Metals in the hydrocycle. Springer, Berlin

52. Townsend AT, Palmer AS, Stark SC, Samson C, Scouller RC, Snape I (2007) Trace metal characterization of marine sediment reference materials MESS- 3 and PACS- 2 in dilute $\mathrm{HCl}$ extracts. Mar Pollut Bull 54(2):236-239. https://doi.org/10.1016/j.marpo Ibul.2006.10.015

Publisher's Note Springer Nature remains neutral with regard to jurisdictional claims in published maps and institutional affiliations. 